\title{
Trust-Significance, Definitions and Dimensions: A Literature Search
}

\author{
Dr. Sheikh Shamim Hasnain \\ The British University in Egypt
}

\begin{abstract}
This is a literature based paper addressing the significance, definitions and dimensions of trust. Trust is a crucial subject matter for many social science disciplines. Researchers could reveal that trust reduces risk, increases productivity, builds a strong relationship between the colleagues in the work place, helps in transferring knowledge between the individuals and organisations, builds team work, minimizes controls, reduces expenditures, reduces competitive attitudes and makes decision making easy. Trust is difficult to define. Researchers and theorists have defined trust in different ways. Trust is defined in numerous ways. Trust dimensions show the various elements and ingredients of trust constituting trust. The definitions and dimensions of trust identified by the researchers are frequently repetitive and concurrent. Future researchers may empirically examine the impact of trust dimension on various issues in the organisations
\end{abstract}

Key Words: Trust, Definitions and Dimensions

\section{INTRODUCTION}

Trust is a multi-disciplinary theme. It is a subject matter of many social science disciples (Bhattacherjee, 2002; Hasnain, 2017) occupying an indispensable criterion for solving many social and organisational anxieties. In any environment where trust prevails, individuals may work comfortably and without any panic. Lucas (2005) claims, "trust allows one to focus on other issues knowing that those with whom we are involved will either protect our interests or not engaged in activities that are harmful" (p. 89). Many researchers (Zaheer, McEvily and Perrone, 1998; McEvily, Perrone and Zaheer, 2003; Ashleigh and Stanton, 2001; Gutteling, Hanssen, van der Veer, and Seydel, 2006; Poppo, Zhou and Ryu, 2008; Parks, Henager and Scamahorn, 1996; Abrams, Cross, Lesser and Levin, 2003; Staples and Webster, 2008; Renzl, 2008; Lucas, 2005; Holste and Fields, 2005; Ashleigh, Connell and Klein, 2003; Becerra, Lunnan and Huemer, 2008; Usoroet al., 2007; Wang, Ashleigh and Meyer, 2006; Mayer, Davies and Schoorman, 1995; Nahapiet and Ghoshal, 1998; Tsai and Ghoshal, 1998; McAllister, 1995) have investigated the impact of trust on numerous issues.So it is crucial to know the significance, definitions and dimensions of this crucial variable and this paper addresses these issues.

\section{A BRIEF DISCUSSION ON SIGNIFICANCE OF TRUST}

In the organisations where trusting atmosphere prevails colleagues may rely on the behaviour of each other and helps to make a strong informal society. Trust helps to increase interdependency and minimizes risks in working relationships (Mayer, Davis and Schoorman, 1995) and thus a harmonious working atmosphere develops. Knowledge transfer is essential in the organisations. Without trust knowledge transfer is difficult. Trust ensures learning from each other (Nonaka and Takeuchi, 1995).For example, the employees may learn the techniques and procedures from the experienced colleagues through knowledge transfer.

It is difficult for the managers to work without delegation. Delegation reduces the work load and responsibilities of the leaders and managers. Trust ensures effective delegation 
(Castelfranchi and Falcone, 1998) to the subordinates and colleagues. So trust reduces the centralisation of power in the organisation and helps the organisations to be more democratic. Trust helps in team working (Pyöriä, 2007), leadership (Bennis and Nanus, 1985), theproduction and supply of quality products and services (Peterson, 1998). It works as the lubrication in the organisational process (Bijlsma and Koopman, 2003; Bennis and Nanus, 1985) and helps to avoid unnecessary interactions (Pyöriä, 2007), ensures less control and reduces expenditure (Creed and Miles, 1996) and also helps to prevent any waste of time.

At the macro level trust makes significant contributions. In this regard Fukuyama (1996) found, "one of the most important lessons we can learn from an examination of economic life is that a nation's well-being, as well as its ability to compete, is conditioned by a single, pervasive cultural characteristic: the level of trust inherent in the society" (p. 7). More specifically, a country's prosperity is directly related to the trusting attitude of that nation. A trusting atmosphere among the citizens of a country helps to accelerate its socio-economic development.

Trust makes the decision making process easy and helps in generating quality decisions. McEvily, Perrone and Zaheer (2003) argue that, "trust makes decision making more efficient by simplifying the acquisition and interpretation of information" (p. 93). They continued by arguing, "trust also guides action by suggesting behaviours and routines that are most viable and beneficial under the assumption that the trusted counterpart will not exploit one's vulnerability" (p. 93). For example, in many cases the beneficiaries of social organisations disclose their confidential personal information to social workers, trusting that the latter would show them the right remedial measures and that their personal information will not be misused or exploited.

Trust helps in eliminating jealousy and non-cooperative movements. Parks, Henager and Scamahorn's (1996) study findsthat high trust reduces competitive attitudes and creates cooperative attitudes. They argued, "the response to one's intentions is affected by the level of trust the opponent holds: high trusters respond to cooperative messages; low trusters response to competitive messages (p. 148). Again, several researchers, (Rotter, 1980; JohnsonGeorge and Swap, 1982; Swap and Rubin, 1983; Larzelere and Huston, 1980; Rempel, Holmes, Zana, 1985) highlighted the important role of trust in close relationships. Trust is the main phenomenon in human relationships, and has powerful capabilities and consequences in close human social bonds.

In the organisations, untrustworthy atmosphere has various adverse impacts. Creed and Miles (1996) exhibit the cost factors associated with control mechanisms in organisations, and the costs of building trust to meet minimal requirements. Showing the consequences and the impacts of trust failure in different structures of organisations, they concluded by arguing "... in the functional forms, trust failures reduce efficiency; in divisional forms they reduce effectiveness, and raises costs; in matrix forms, they cause the form to fail; and in networks, they cause the firms to fail." (p. 26). Ultimately such organisations fail to achieve their strategic and social intents in the business environment.

Trust works as a strong monitoring tool in any context. Trust as an informal control mechanism helps to decrease friction, puts spontaneous restrictions on opportunistic behaviour, shrinks bureaucratic roles, encourages potential dealings and sets up long term relationships (Bhattacherjee, 2002). Thus trust works as a magical catalyst in the organisations. 


\section{TRUST-DEFINITIONS AND DIMENSIONS}

The dimensions of trust are the ingredients borrowed from the trust definitions, or vice versa. It is difficult to define trust (Huotari and Livonen, 2004; Holste, 2003; Holste \& Fields, 2010). Trust is a complicated construct, though it has abundant definitions (Rousseau, Sitkin, Burt and Camerer, 1998). A few important definitions of trust are: (i) "The willingness of a party to be vulnerable to the actions of another party based on expectation that the other will perform a particular action important to the truster, irrespective of the ability to monitor or control that party" (Mayer, Davis and Schoorman, 1995, p.712) (ii) "Trust is a psychological state comprising the intention to accept vulnerability based upon positive expectations of the intentions or behavior of another" (Rousseau et al., 1998, p.395) (iii) "Trust is the expectation that arises within a community of regular, honest, and cooperative behaviour, based on commonly shared norms, on the part of other members of that community" (Fukuyama , 1996, p. 26) (iv) "An expectancy held by an individual or a group that the word, promise, verbal or written statement of another individual or group can be relied upon" (Rotter, 1967, p. 651) (v) "A social resource which can be drawn upon to achieve organisational goal" (Ashleigh, Connell and Klein, 2003, p. 2) (vi) "A belief by a person in the integrity of another person" (Larzelere and Huston , 1980 p. 595) (vii) "The extent to which a person is confident in, and willing to act on the basis of, the words, actions, and decisions of another" (McAllister, 1995, p. 25) (viii) “ Trust is one party's willingness to be vulnerable to another party based on the belief that the later party is (a) competent, (b) open, (c) concerned, and (d) reliable (Mishra, 1996, p.265) (ix) "Trust is practised and exercised between individuals, even if they "stand for" an organisation" (Hoecht and Trott (1999, p. 260) (x) "Trust is an actor's expectation of the other party's capability, goodwill and self reliance, which needs to be confirmed by experience. Thus, trust is increased by- and decreased by the lack of-evidence of these components in parties actual behavior and communication" (Blomqvist and Ståhle, 2004, p. 180) (xi) "An individual's belief or a common belief among a group of individuals that another individual or group (1) makes good-faith efforts to behave in accordance with any commitments both explicit or implicit, (2) is honest in whatever negotiations preceded such commitments, and (c) does not take excessive advantage of another even the opportunity is available" (Cummings and Bromiley, 1996, p. 303) and (xii) "Trust is a bet about the future contingent actions of others" (Sztompka, 1999, p. 25).

Fukuyama's (1995) definition of trust enveloped the vital factors of regularity, honesty and cooperation in behaviour. Similarly, Rousseau et al. (1998) emphasised the positive behaviour of parties in the definition. Mishra (1996) highlighted issues of competency, openness, concerns and reliability.

Blomqvist and Ståhle (2004) identify trust as an interaction between expectations and the demonstration of those expectations in the real behaviour of the parties involved. In Fukuyama's (1996) definition of trust, honesty and cooperative behaviour were emphasized, while the attribute of ability is incorporated in the definition of Mayer, et al. (1995). Usoroet al., (2007) had empirical study on the impact of benevolence, integrity and ability on knowledge transfer. They (2007) found that the dimensions of Mishra's (1996) definition, concern, reliability, and competence, are a mirror to the definition of Mayeret al. (1995). It clear that this definition is focused on human personality traits. Many definitions (Mishra, 1996; Usoro et al., 2007) cited above, echo similar views and opinions to Mayer et al. (1995), whose definition of trust is intensively used and has been cited by many theorists and researchers (Rousseau et al., 1998; Lucas, 2005; Ashleighet al.,2003; Usoro et al., 2007; Li, 2005; Szulanski, Cappetta and Jensen, 2004; Levin and Cross, 2004; Bhattacherjee , 2002; Hoell, 2004; McEvily, Perrone and Zaheer, 2003; Ashleigh and Stanton, 2001; Levin, Whitener and Cross, 2006; Ford, 2004) . Mayer, et al. (1995) defined trust as, "the willingness of a party to be vulnerable to the 
actions of another party based on expectation that the other will perform a particular action important to the trustor, irrespective of the ability to monitor or control that party" (p. 712). In their model of trust (p. 715), the three factors of ability, benevolence and integrity of another party are identified as the basis of trust. Mayer et al.(1995) also differentiated trust from cooperation, confidence and predictability. They argued that without trust cooperation may take place, as trust is not an essential prerequisite to cooperation. Regarding confidence, they referred to Luhmann (1988) who differentiated confidence from trust, arguing that trust is associated with risk, that is, the question of trust comes where there is risk. Confidence eliminates risk. Further, Mayer et al. (1995) also differentiated predictability from trust, arguing that predictablity reduces risk and trust must go beyond predictability to face vulnerability. They cited an example, "if a person's superior always 'shoots the messenger' when the bad news is delivered, the superior is predictable. However, that predictability will not increase the likelihood that the individual will take a risk and deliver bad news. On the contrary, predictability can reduce the likelihood that the individual will trust and therefore take actions that allow venerability to the superior." (p. 714). Trust is contextual and may vary in different situations. Several authors (Fukuyama, 1995; Mayer, et al.,1995; Mishra, 1996; Rempel, Holmes and Zanna, 1985; Butler, 1991; Cummings and Bromiley, 1996; Doney and Cannon, 1997; Zaheer, McEvily and Perrone, 1998) have identified different trust antecedents and factors on which the actions of the actors involved in the transaction depend.

The following are the dimensions, or antecedents of trust identified by researchers: (i) Regularity, honesty and cooperation (Fukuyama, 1996) (ii) Ability, benevolence and integrity (Mayer, et al. , 1995) (iii) (a) Competence dimension of trust (b) openness dimension of trust (c) concern dimension of trust (d) reliability dimension of trust (Mishra, 1996) (iv) Capability, good will and self reliance (Blomqvist and Ståhle, 2004) (v) Availability, competence, consistency, discreetness, fairness, integrity, loyalty, openness, promise fulfilment and receptivity (Butler, 1991) (vi) Benevolence and honesty (Larzelere and Huston, 1980) (vii) Predictability, dependability and faith (Rempel, Holmes and Zanna, 1985) (viii) Behaviourally reliable, fulfil commitments and does not take excessive advantages (Cummings and Bromiley, 1996) (ix) Credibility (e.g. words and statement can be relied upon) and benevolence ( parties are motivated for joint gains and welfare) (Doney and Cannon, 1997) (x) Reliability, predictability and fairness (Zaheer, McEvily and Perrone, 1998) (xi) Emotive constructs (confidence, respect, commitments and team work), cognitive constructs (understanding : knowledge, experience and familiarity) and behavioural constructs ( honesty, reliability, proactive, performance, communication and quality of interaction) (Ashleigh and Stanton, 2001) (xii) Beliefs and commitment (Sztompka, 1999) (xiii) Reliability and reputation (Von Krogh, Ichijo and Nonaka, 2000) (xiv) Trust= trust in knowledge+ trust in capabilities + trust in values + Trust in integrity (Ashleigh, Connell and Klein, 2003) (xv) Faith, dependability and predictability (Rempel, Holmes and Zanna, 1985) (xvi) Competence ( competent, expert, dynamic), predictability ( predictable), benevolence (good, moral, good will, benevolent, caring, responsive), integrity ( honest, credible, reliable, dependable) and others ( open, careful, safe, shared understanding and personally attractive) (McKnight and Chervany, 2001) (xvii) Honesty, integrity and reliability (Coote, Forrest and Tam, 2003) (xviii) Reliability, predictability and faith (Dyer and Chu, 2000) (xix) Confidence, reliability and integrity (Aulakh, Kotabe and Sahay , 1996) (xx) Dependability, predictability and faith (Young-Ybara and Wiersema, 1999) and (xxi) Emotive constructs (confidence, commitment, team-work, respect), cognitive constructs (understanding, ability, expectancy), behavioural constructs (honesty, reliability, proactive, performance, communication, quality of interaction) (Ashleigh and Stanton, 2001). 


\section{CONCLUSION AND FUTURE RESEARCH}

Trust is a crucial ingredient of many social science disciplines. It is one of the indispensible panacea to many social and organisational problems. Trust helps to develop a good working relationship in the organisations and managers may delegate their authorities and responsibilities to the subordinates comfortably. Trust works like lubricants by which organisations may develop effective and smooth teams, leaders and control mechanisms. Many researchers and theorists find it as a catalyst to smooth functioning of the nations and the organisations. Numerous fruitful advantages are described by the authors. Some of them find that (i) trust makes the decision making effective and simple (ii) trust reduces competitive attitudes (iii) trust helps developing close human relationships (iv) trust makes the organisations' control mechanisms easy and effective (v) trust reduces costs in the organisations (vi) trust increases organisational efficiency (vii) trust ensures quality and helps to increase productivity. It is not easy to define trust. There are many definitions and dimensions oftrust. They are often concurrent and repetitive in nature. Some definitions and dimensions areoverlapping with each other. Regularity, honesty and cooperation arethe ingredients of Fukuyama's (1995) trust, while Mayer et al. (1995) have ability, benevolence and integrity. Usoro et al. (2007) and Mishra (1996) definitions of trust are echoing the trust dimensions of Mayer et al. (1995). The maximum trust dimensions (e.g. ability, benevolence and integrity) presented by Mayer et al (1995). However, earlier the trust dimensions like benevolence and honesty was given by Larzelere and Huston (1980). Highlighting the trust dimensions, Ashleigh and Stanton comprehensively shows " Emotive constructs (confidence, respect, commitments and team work), cognitive constructs (understanding : knowledge, experience and familiarity) and behavioural constructs ( honesty, reliability, proactive, performance, communication and quality of interaction)". Future Researchers may empirically investigate the definitions and dimensions of trust in any organisational context.

\section{References}

Abrams, L.C., Cross, R.., Lesser, E. \& Levin, D.Z. (2003). Nurturing interpersonal trust in knowledge-sharing networks. Academy of Management Executive,17 (4), 64-77.

Ashleigh, M. J. \& Stanton, N. A.( 2001). Trust: Key elements in human supervisory control domains. Cognition Technology \& Work, 3, 92-100.

Ashleigh, M., Connell, C. \& Klein, J. H. (2003, October). Trust and knowledge transfer: An explanatory framework for identifying relationships within communities of practice. The EIASM Second Workshop on Trust Within and Between Organisations, Amsterdam.

Aulakh, P.S., Kotabe, M. \& Sahay, A. (1996). Trust and performance in cross-border marketing partnerships: A behavioral approach. International Business Studies, 27 (5), 1005-1032.

Bennis, W. G. \&Nanus, B. (1985). Leaders: The Strategies for Taking Charge. NY: Harper \& Row.

Bhattacherjee, A. (2002). Individual trust in online firms: Scale development and initial test. Journal of Management Information Systems, 19 (1), 211-241.

Bijlsma, K. \&Koopman, P. (2003). Introduction: trust within organisations. Personnel Review, 32 (5), 543-555.

Blomqvist, K. \&Ståhle, P. (2004). Trust in technology parternerships. In M. Huotari \& M.

Livonen (Eds.), Trust in Knowledge Management and Systems in Organizations. London: Idea Group Publishing, pp. 173-199.

Butler, J. K. (1991). Toward understanding and measuring conditions of trust: Evolution of a conditions of trust inventory. Journal of Management, 17 (3), 643-663.

Castelfranchi, C. \& Falcone, R. (1998). Towards a theory of delegation for agent based-system. Robotics and Autonomous Systems, 24 (3-4), 141-157

Creed, W.E.D. \& Miles, R. E. ( 1996). Trust in organizations: A conceptual framework linking organizational forms, managerial philosophies, and the opportunity costs of controls. In R. M. Kramer \& T. R. Tyler ( Eds.), Trust in Organizations: Frontiers of Theory and Research (pp.16-38), Thousand Oaks, CA: Sage Publications, Inc. 
Coote, L., Forrest, E. J. and Tam, T. W. (2003). An investigation into commitment in non-Western industrial marketing relationships. Industrial Marketing Management, 32 (7), 595-604.

Cummings, L. L. \& Bromiley, P. (1996). The organizational trust inventory (OTI): Development and validation. In R.M. Kramer \& T. R. Tyler (Eds.), Trust in Organizations: Frontiers of Theory and Research, (pp. 302-330).

Thousand Oaks, CA: Sage Publications, Inc.

Doney, P. M.\& Cannon, J. P. (1997). An Examination of the nature of trust in Buyer-seller relationships. The Journal of Marketing, 61, 35-51

Dyer, J. H. \& Chu, W. (2000). The determinants of trust in supplier-automaker relationships in the US, Japan, and Korea. Journal of International Business Studies, 31 (2), 259-285.

Ford, D. P. (2004). Trust and knowledge management: The seeds of success. In Clyde W. Holsapple (Ed.), Handbook on Knowledge Management 1 Knowledge matters, (pp.553-575), Heidelberg (Germany): Springer-Verlag

Fukuyama, F. (1996). Trust: The Social Virtues and the Creation of Prosperity. NY: Simon \& Schster Inc.

Hasnain, S. S. (2017). Trust-A Catalyst to Knowledge Transfer: Contemporary Studies. Advances in Social Sciences Research Journal, 4 (1), 29-40.

Hoect, A. \&Trott, P. ( 1999). Trust risk and control in the management of collaborative Technology development. International Journal of Innovation Management, 3 (3), 257-270.

Hoell, R. C. ( 2004). The effect of interpersonal trust and participativeness on union member commitment. Journal of Business and Psychology, 19 (2), 161-177

Holste, J. S. \& Fields, D. (2010). Trust and tacit knowledge sharing and use. Journal of Knowledge Management, 14(1), 128-140.

Huotari, M. \& Livonen, M. ( 2004). Managing knowledge-based organizations through trust. In M. Huotari \& M. Livonen (Eds.), Trust in Knowledge Management and Systems in Organizations. London: Idea Group Publishing, pp. $1-15$

Larzelere, R. E. \& Huston, T. L. (1980). The Dyadic trust scale. Journal of Marriage and the Family, 42 (3), 595-604. Johnson-George, C. \& Swap, W. C. (1982). Measurement of specific interpersonal trust: Construction and validation of a scale to assess trust in a specific other. Journal of Personality and Social Psychology, 43 (6), 1306-1317.

Larzelere, R. E. \& Huston, T. L. (1980). The Dyadic trust scale. Journal of Marriage and the Family, 42 (3), 595-604. Levin, D. Z. \& Cross, R. (2004). The strength of weak ties you can trust : the mediating role of trust in effective knowledge transfer. Management Science, 50 (11), 1477-1490.

Levin, D. Z., Whitener, E.M. \& Cross, R. (2006). Perceived trustworthiness of knowledge sources : The moderating impact of relationship length. Journal of Applied Psychology, 91(5), 1163-1171.

Li, L. (2005). The effects of trust and shared vision on inward knowledge transfer in subsidiaries' intra-and interorganizational relationships. International Business Review, 14, 77-95.

Lucas, L. M. (2005). The impact of trust and reputation on the transfer of best practices. Journal of Knowledge Management, 9 (4), 87-101

Luhmann, N. (1988). Familiarity, confidence, trust: Problems and alternatives. In D. G. Gambetta (Ed.), Trust: $94-$ 107.

Mayer, R.C., Davis, J.H. \&Schoorman, F.D. (1995). An integrative model of organizational trust. Academy of Management Review, 20 (3), 709-734

McAllister,D.J. (1995).Affect- and cognition-based trust as foundations for interpersonal cooperation in organizations. The Academy of Management Journal, 38(1),24-59.

McEvily, B., Perrone, V. \&Zaheer, A. (2003). Trust as an Organizing Principle. Organization Science, 14 (1), 91-103.

McKnight, D. H. \&Chervany, N. L.(2001-2002, Winter). What trust means in e-commerce customer relationships: An interdisciplinary conceptual typology. International Journal of Electronic Commerce, 6 (2), 35-59.

McKnight, D. H., Cummings, L. L. \&Chervany, N. L. (1998). Initial trust formation in new organizational relationships. The Academy of Management Review, 23 (3), 473- 490.

Mishra, A. K. (1996). 'Organizational response to crisis: The century of trust', in R. M. Kramer \& T. R. Tyler ( eds.), Trust in Organizations: Frontiers of Theory and Research, California: Sage Publications, pp. 261-287. 
Nahapiet, J. \&Ghosal, S. (1998). Social capital, intellectual capital, and the organizational advantage, The Academy of Management Review, (2) 23, 242-266.

Nonaka, I. \& Takeuchi, H. (1995). The Knowledge Creating Company. Oxford: Oxford University Press.

Parks, C. D., Henager, R. F. \&Scamahorn, S. D. (1996). Trust and reactions to messages of intent in social dilemmas. The Journal of Conflict Resolution, 40 (1), 134-151.

Peterson, R. (1998). Trust for quality. The TQM magazine, 10 (6), 413-416.

Poppo, L., Zhou, K. Z. \&Ryu, S. (2008). Alternative origins to internationalizational trust: An interdependence perspective on the shadow of the past and the shadow of the future. Organization Science, 19 (1), 39-55.

Pyöriä, P. (2007). Informal organizational culture: The foundation of knowledge workers' performance. Journal of Knowledge Management, 11(3), 16-30.

Rempel, J. K., Holmes, J. G. \&Zanna, M. P. (1985). Trust in close relationships. Journal of Personality and Social Psychology, 49 (1), 95-112

Renzl, B. (2008). Trust in management and knowledge sharing: The mediating effects of fear and knowledge documentation. Omega, 36(2), 206-220.

Rotter, J. B. (1967). A new scale for measurement of interpersonal trust. Journal of Personality, 35 (4), 651-665.

Rotter, J. B. (1980). Interpersonal Trust, Trustworthiness, and Gullibility. American Psychologist, 35 (1), 1-7

Rousseau, D. M., Sitkin, S. B., Burt, R. S. and Camerer, C. (1998). Not so different after all: A cross discipline view of trust. The Academy of Management Review, 23 (3), 393-404.

Staples, D. S. \& Webster, J. (2008). Exploring the effects of trust, task interdependence and virtualness on knowledge sharing in teams. Information Systems Journal, 18, 617-640.

Swap, W.C. \& Rubin, J. Z. (1983). Measurement of interpersonal orientation. Journal of Personality and Social Psychology, 44 (1), 208-219.

Sztompka, P. (1999). Trust: A Sociological Theory. Cambridge: Cambridge University Press

Szulanski,G., Cappetta, R. \& Jensen, R.J.(2004). When and how trustworthiness Matters: Knowledge transfer and the moderating effect of casual ambiguity. Organization Science, 15 (5), 600-613.

Usoro, A., Sharratt, M. W., Tsui, E. \&Shekhar, S. (2007). An inVaustment into trust as an antecedent to knowledge sharing in virtual communities of practice. Knowledge Management Research and Practice, 5, 199-212.

von Krogh, G., Ichijo, K. \& Nonaka, I. (2000). Enabling Knowledge Creation: How to Unlock the Mystery of Tacit Knowledge and Release the Power of Innovation. NY: Oxford University Press Inc.

Webb, E. J.(1996). Trust and crisis. In R. M. Kramer \& T. R. Tyler (Eds.), Trust in Organizations: Frontiers of Theory and Research, (pp.288-301). Thousand Oaks, CA: Sage Publications, Inc.

Young-Ybarra, C. \& Wiersema, M.F. (1999). Strategic flexibility in information technology alliances: The influence of transaction cost economics and social exchange theory. Organization Science, 10 (4), 439-459.

Zaheer, A., McEvily, B. \& Perrone, V. (1998). Does trust matter? Exploring the effects of interorganizational and interpersonal trust on performance. Organization Science, 9 (2), 141-159. 